\title{
Pengaruh Orang Tua, Pengetahuan dan Teman Sebaya Terhadap Perilaku Seksual Remaja
}

Yuhemy Zurizah

Akademi Kebidanan Budi Mulia Palembang

\section{Informasi Artikel :}

Diterima : 30 Maret 2020

Direvisi : 12 April 2020

Disetujui : 30 April 2020

*Korespondensi Penulis : yuhemyz@gmail.com

\begin{abstract}
A B S T R A K
Hasil survey PKBI menyatakan bahwa hampir $50 \%$ remaja Indonesia melakukan hubungan seks di luar nikah. Banyak faktor yang mempengaruhi perilaku seksual remaja antara lain yaitu perubahan biologis yang terjadi pada masa pubertas, pengaruh orang tua, pengetahuan, pengaruh teman sebaya, Perspektif sosial kognitif, Remaja dengan prestasi rendah. Tujuan penelitian ini adalah untuk mengetahui hubungan pengaruh orang tua, pengetahuan dan teman sebaya terhadap perilaku seksual remaja. Jenis penelitian ini bersifat survey analitik, metode yang dipakai menggunakan pendekatan Cross Sectional. Populasi pada penelitian ini adalah seluruh siswa - siswi SMK Karya Ibu Palembang. Tehnik pengambilan sampel dalam penelitian ini adalah total sampling yaitu 112 responden. Penelitian dilakukan pada bulan Januari - Februari 2020. Kesimpulan dalam penelitian ini adalah ada hubungan bermakna antara pengaruh orang tua dengan perilaku seksual remaja dengan p.value yaitu 0,001 . Ada hubungan bermakna antara pengetahuan dengan perilaku seksual remaja dengan $p$ value yaitu 0,039 . Ada hubungan bermakna antara pengaruh teman sebaya dengan perilaku seksual remaja dengan $p$ value yaitu 0,025 .
\end{abstract}

\section{Kata Kunci : Perilaku seksual remaja, Perilaku seks bebas.}

\begin{abstract}
PKBI survey results state that nearly 50\% of Indonesian teenagers have sex outside of marriage. Many factors affect adolescent sexual behavior including biological changes that occur during puberty, parental influence, knowledge, peer influence, social cognitive perspective, adolescents with low achievement. The purpose of this study was to determine the relationship of parental influence, knowledge and peers to adolescent sexual behavior. This type of research is analytic survey, the method used is cross sectional approach. The population in this study were all students of SMK Karya Ibu Palembang. The sampling technique in this study was a total sampling of 112 respondents. The study was conducted in January - February 2020. The conclusion in this study is that there is a significant relationship between the influence of parents with adolescent sexual behavior with p.value which is 0.001. There is a significant relationship between knowledge with adolescent sexual behavior with a $p$ value of 0.039. There is a significant relationship between peer influence and adolescent sexual behavior with a $p$ value of 0.025 .
\end{abstract}

Keywords: Adolescent sexual behavior, Free sex behavior 


\section{PENDAHULUAN}

Remaja mempunyai karakteristik yang khas dalam suatu periode kehidupan. Berbagai perubahan dari segala aspek biologis, psikologis, sosial maupun budaya. Remaja mempunyai sifat yang unik, salah satunya adalah sifat ingin meniru sesuatu hal yang dilihat pada lingkungan disekitarnya. Begitu juga halnya dengan wanita yang memiliki kekhasan tersendiri. Wanita memiliki kebutuhan kesehatan khusus yang berhubungan dengan fungsi seksual dan reproduksi. ${ }^{1}$

Menurut World Health Organization (WHO) remaja adalah periode usia antara 10-19 tahun, sedangkan menurut Perserikatan BangsaBangsa (PBB) remaja adalah kaum muda untuk usia antara 15-24 tahun. Sementara itu, menurut The Health Resources and Services Adminitrations Guidelines Amerika Serikat, rentang usia remaja adalah 11-21 tahun dan terbagi menjadi tiga tahap, yaitu remaja awal 1114 tahun, remaja menengah 15-17 tahun dan remaja akhir 18-21 tahun. ${ }^{1}$

Pada tahun 2010 Perkumpulan Keluarga Berencana Indonesia (PKBI) melakukan survey pada lima kota, diantaranya Bandung, Jakarta dan Yogyakarta. Hasil survey PKBI menyatakan bahwa hampir $50 \%$ remaja Indonesia melakukan hubungan seks di luar nikah. Sementara penelitian pada tahun 2011 dilakukan terhadap 2.488 responden di Tasikmalaya, Cirebon, Singkawang, Palembang dan Kupang menemukan bahwa sebanyak $85 \%$ remaja berusia 13 sampai 15 tahun mengaku telah berhubungan seks dengan pacar mereka, $52 \%$ yang memahami bagaimana kehamilan bisa terjadi, $50 \%$ dari remaja itu mengaku menonton media pornografi, diantaranya VCD dan hubungan seks itu dilakukan dirumah sendiri. ${ }^{2}$

Perilaku seksual remaja dapat disebabkan oleh rendahnya pengetahuan remaja tentang seks dan karena kurangnya informasi. Menurut hasil penelitian para dokter di Jakarta seperti yang dikutip oleh Dr. Boyke bahwa 10-12\% remaja pengetahuan seksnya sangat kurang. ${ }^{3}$

Data Survei Kesehatan Reproduksi Remaja Indonesia terakhir Badan Koordinasi Keluarga Berencana (BKKBN) menyebutkan sebanyak 5.912 wanita diumur 15-19 tahun secara nasional pernah melakukan hubungan seksual. Sedangkan pria di usia yang sama berjumlah 6.578 orang atau $3,7 \%$ dari jumlah remaja Indonesia pernah melakukan hubungan seks dan setiap tahun ada sekitar 2,3 juta kasus aborsi dimana 20\% dilakukan remaja. ${ }^{4}$

Pada remaja masa pencarian jati diri yang mendorongnya mempunyai rasa keingintahuan yang tinggi, ingin tampil menonjol, dan diakui eksistensinya. Namun disisi lain remaja mengalami ketidakstabilan emosi sehingga mudah dipengaruhi teman dan mengutamakan solidaritas kelompok. Diusia remaja, akibat pengaruh hormonal, juga mengalami perubahan fisik yang cepat dan mendadak. Perubahan ini ditunjukan dari perkembangan organ seksual menuju kesempurnaan fungsi serta tumbuhnya organ genetalia sekunder. Hal ini menjadikan remaja sangat dekat dengan permasalahan seputar seksual. Namun terbatasnya bekal yang dimiliki menjadikan remaja memang masih memerlukan perhatian dan pengarahan. ${ }^{5}$

Ketidakpekaan orang tua atau pengaruh orang tua terhadap kondisi remaja menyebabkan remaja sering terjatuh pada kegiatan tuna sosial. Ditambah lagi keengganan dan kecanggungan remaja untuk bertanya pada orang yang tepat semakin menguatkan alasan kenapa remaja sering bersikap tidak tepat terhadap organ reproduksinya. Data menunjukan dari remaja usia 12-18 tahun, 16\% mendapat informasi soal seks dari teman, $35 \%$ dari film porno, dan $5 \%$ dari orang tua. Hubungan seks diluar pernikahan menunjukan tidak adanya rasa tanggung jawab dan memunculkan rentetan persoalan baru yang menyebabkan gangguan fisik dan psikolososial manusia. ${ }^{5}$

Pengetahuan remaja mengenai dampak seks bebas masih sangat rendah yang paling menonjol dari kegiatan seks bebas yaitu dengan meningkatnya angka kehamilan yang tidak diinginkan. Setiap tahun ada sekitar 2,3 juta kasus aborsi dimana $20 \%$ dilakukan remaja ${ }^{2}$

Pada usia remaja seseorang menghabiskan lebih banyak waktunya bersama dengan teman sebayanya di bandingkan dengan orang tuanya, sehingga wajar saja jika tingkah laku dan norma/aturan-aturan yang dipegang banyak dipengaruhi oleh kelompok sebayanya. Ketergantungan kepada teman sebaya lebih mengarah pada hal-hal yang berkaitan dengan relasi sosial atau penerimaan lingkungan (misalnya tingkah laku/kebiasaan sehari-hari, kesukaan, aktivitas yang dipilih, gaya bahasa dan lain-lain. ${ }^{1}$

Banyak faktor yang mempengaruhi perilaku seksual remaja antara lain yaitu perubahan biologis yang terjadi pada masa pubertas, pengaruh orang tua, pengetahuan, 
pengaruh teman sebaya, Perspektif sosial kognitif, Remaja dengan prestasi rendah. ${ }^{1}$

Faktor lain yang berhubungan dengan perilaku seksual remaja antara lain faktor internal (tingkat perkembangan seksual, pengetahuan mengenai kespro dan motivasi), sedangkan faktor eksternal (keluarga atau orang tua, pengaruh teman sebaya dan media masa) ${ }^{.6}$

Berdasarkan latar belakang tersebut peneliti tertarik untuk melakukan penelitian mengenai Pengaruh Orang Tua, Pengetahuan dan Teman Sebaya Terhadap Perilaku Seksual Remaja di SMK Karya Ibu Palembang.

\section{METODE PENELITIAN}

Jenis penelitian ini bersifat survey analitik, metode yang dipakai menggunakan pendekatan Cross Sectional, dimana pengumpulan data baik variabel Independen (pengaruh orang tua, pengetahuan dan pengaruh teman sebaya) maupun variabel Dependen (perilaku seksual) dilakukan dalam waktu bersamaan. ${ }^{7}$

pada penelitian ini adalah seluruh siswa siswi SMK Karya Ibu Palembang. Tehnik pengambilan sampel dalam penelitian ini adalah total sampling yaitu 112 responden. Penelitian dilakukan pada bulan Januari - Februari 2020.

Data primer diambil dengan cara pembagian angket kepada responden. Data sekunder diperoleh dari dokumen kesiswaan SMA Karya Ibu Palembang. Analisis Univariat dilakukan terhadap variabel dari hasil penelitian yaitu variabel independen (pengaruh orang tua, pengetahuan dan pengaruh teman sebaya) dan variabel dependen (perilaku seksual remaja) dalam bentuk distribusi frekuensi yang bertujuan untuk melihat distribusi frekuensi dari tiap-tiap variabel. Analisis bivariat dilakukan untuk mengetahui hubungan antara variabel independen (pengaruh orang tua, pengetahuan dan pengaruh teman sebaya) dan variabel dependen (perilaku seksual remaja) menggunakan uji statistik "ChiSquare", dengan tingkat kemaknaanya $\alpha=0,05$.

\section{HASIL PENELITIAN}

\section{A. Analisa Univariat \\ 1. Pengaruh Orang Tua}

Penelitian ini dilakukan pada 112 responden dimana pengaruh orang tua dibagi menjadi 2 kategori yaitu pengaruh orang tua baik dan pengaruh orang tua yang kurang baik, untuk lebih jelasnya dapat dilihat pada 1 di bawah ini :
Tabel 1 Distribusi frekuensi Responden Berdasarkan Pengaruh Orang Tua Terhadap Perilaku Seksual Remaja di SMK Karya Ibu Palembang

\begin{tabular}{clcc}
\hline No & $\begin{array}{c}\text { Pengaruh Orang } \\
\text { Tua }\end{array}$ & N & \% \\
\hline 1 & Baik & 89 & $\mathbf{7 9 . 5}$ \\
\hline 2 & Kurang & 23 & $\mathbf{2 0 . 5}$ \\
\hline & Total & $\mathbf{1 1 2}$ & $\mathbf{1 0 0}$ \\
\hline
\end{tabular}

Dari tabel diatas dapat di lihat bahwa responden dengan pengaruh orang tua yang baik sebanyak 89 reponden $(79,5 \%)$ dan pengaruh orang tua yang kurang sebanyak 23 responden $(20,5 \%)$.

\section{Pengetahuan}

Penelitian ini dilakukan pada 112 responden dimana pengetahuan di bagi menjadi 2 kategori yaitu pengetahuan baik dan pengetahuan yang kurang, untuk lebih jelas dapat di lihat pada tabel 2 di bawah ini :

Tabel 2 Distribusi Frekuensi Responden Berdasarkan Pengetahuan Tentang Perilaku Seksual di SMK Karya Ibu Palembang

\begin{tabular}{|c|c|c|c|}
\hline No & Pengetahuan & $\mathbf{N}$ & $\%$ \\
\hline 1 & Baik & 71 & 63.4 \\
\hline 2 & Kurang & 41 & 36.6 \\
\hline & Total & 112 & 100 \\
\hline
\end{tabular}

Dari tabel diatas dapat dilihat bahwa responden dengan pengetahuan baik sebanyak 71 reponden $(63,4 \%)$ dan responden yang berpengetahuan kurang sebanyak 41 responden $(36,6 \%)$.

\section{Pengaruh Teman Sebaya}

Penelitian ini dilakukan pada 112 responden dimana pengaruh teman sebaya di bagi menjadi 2 kategori yaitu pengaruh teman yang baik dan pengaruh teman yang kurang, untuk lebih jelas dapat di lihat pada tabel 3 di bawah ini.

Tabel 3 Distribusi frekuensi Responden Berdasarkan Pengaruh Teman Sebaya Terhadap Perilaku Seksual di SMK Karya Ibu Palembang

\begin{tabular}{llcc}
\hline No & $\begin{array}{c}\text { Pengaruh Teman } \\
\text { Sebaya }\end{array}$ & N & \% \\
\hline 1 & Baik & 88 & 78.6 \\
\hline 2 & Kurang & 24 & 21.4 \\
\hline & Total & $\mathbf{1 1 2}$ & $\mathbf{1 0 0}$ \\
\hline
\end{tabular}

Dari tabel diatas dapat dilihat bahwa responden yang mempunyai teman sebaya 
baik sebanyak 88 reponden $(78,6 \%)$ dan responden yang mempunyai teman sebaya kurang baik sebanyak 24 responden $(21,4 \%)$.

\section{Perilaku Seksual Remaja}

Penelitian ini dilakukan pada 112 responden dimana perilaku seksual remaja di bagi menjadi 2 kategori yaitu perilaku baik dan perilaku buruk, untuk lebih jelas dapat di lihat pada tabel 4 di bawah ini

Tabel 4 Distribusi frekuensi Responden Berdasarkan Pengetahuan di SMK Karya Ibu Palembang

\begin{tabular}{llll}
\hline No & $\begin{array}{c}\text { Perilaku Seksual } \\
\text { Remaja }\end{array}$ & N & \% \\
\hline 1 & Baik & 37 & 33.0 \\
\hline 2 & Buruk & 75 & 67.0 \\
\hline Total & & $\mathbf{1 1 2}$ & $\mathbf{1 0 0}$ \\
\hline
\end{tabular}

Dari tabel diatas dapat dilihat bahwa responden berperilaku seksualBuruksebanyak 75 responden (67\%) dan responden yang berprilaku seksual baik sebanyak 37 responden $(33 \%)$.

\section{B. Analisa Bivariat}

1. Hubungan Pengaruh Orang Tua dengan Perilaku Seksual Remaja

Penelitian ini dilakukan pada 112 responden dimana pengaruh orang tua dikelompokan menjadi 2 kategori yaitu pengaruh orang tua baik dan pengaruh orang tua kurang baik dengan perilaku seksual baik dan perilaku seksual buruk dengan menggunakan uji statistik Chi-Square. Untuk mengetahui lebih jelas dapat di lihat pada tabel 5 di bawah ini :

Tabel 5 Distribusi Hubungan Pengaruh Orang Tua dengan Perilaku Seksual Remaja SMK Karya Ibu Palembang

\begin{tabular}{|c|c|c|c|c|c|c|c|}
\hline \multirow{3}{*}{$\begin{array}{l}\text { Pengaruh } \\
\text { orang tua }\end{array}$} & \multicolumn{4}{|c|}{$\begin{array}{c}\text { Perilaku seksual } \\
\text { remaja }\end{array}$} & \multirow[t]{3}{*}{ Total } & \multirow[t]{3}{*}{$\%$} & \multirow{3}{*}{$\begin{array}{c}P \\
\text { value }\end{array}$} \\
\hline & \multicolumn{2}{|c|}{ Baik } & \multicolumn{2}{|c|}{ Buruk } & & & \\
\hline & $\mathrm{N}$ & $\%$ & $\mathrm{~N}$ & $\%$ & & & \\
\hline Baik & 22 & 24,7 & 67 & 75,3 & 89 & 100 & 0,001 \\
\hline Kurang & 15 & 65,2 & 8 & 34,8 & 23 & 100 & \\
\hline Jumlah & 37 & & 78 & & 112 & & \\
\hline
\end{tabular}

Dari data tabel 5 diatas dapat dilihat bahwa perilaku seksual remaja dengan pengaruh orang tua yang baik berjumlah 89 responden di mana pengaruh orang tua baik dengan perilaku seksual remaja baik sebanyak 22 responden $(24,7 \%)$ lebih sedikit dibandingkan dengan pengaruh orang tua baik dengan perilaku seksual remaja yang buruk sebanyak 67 responden (75,3\%), sedangkan perilaku seksual remaja dengan pengaruh orang tua kurang berjumlah 23 responden yang pengaruh orang tua kurang dengan perilaku seksual remaja yang baik sebanyak 15 responden $(65,2 \%)$ lebih besar di bandingkan dengan pengaruh orang tua kurang dengan perilaku seksual remaja yang buruk sebanyak 8 responden $(34,8 \%)$.

Bila di lihat dari hasil statistik dengan menggunakan Chi-Square menunjukan nilai p.value $(0,001)$ lebih kecil dari $\alpha(0,05)$ artinya ada hubungan bermakna antara pengaruh orang tua dengan perilaku seksual remaja.

\section{Hubungan Pengetahuan dengan Perilaku Seksual Remaja}

Penelitian ini dilakukan pada 112 responden dimana pengaruh orang tua dikelompokan menjadi 2 kategori yaitu pengetahuan baik dan pengetahuan kurang baik dengan perilaku seksual baik dan perilaku seksual buruk dengan menggunakan uji statistik Chi-Square. Untuk mengetahui lebih jelas dapat di lihat pada 6 di bawah ini :

Tabel 6 Distribusi Hubungan Pengetahuan dengan Perilaku Seksual Remaja di SMK Karya Ibu Palembang

\begin{tabular}{|c|c|c|c|c|c|c|c|}
\hline \multirow[t]{3}{*}{ Pengetahuan } & \multicolumn{4}{|c|}{$\begin{array}{c}\text { Perilaku seksual } \\
\text { remaja }\end{array}$} & \multirow{3}{*}{$\begin{array}{l}\text { Total } \\
\mathbf{N} \\
\end{array}$} & \multirow[t]{3}{*}{$\%$} & \multirow{3}{*}{$\begin{array}{c}P \\
\text { value }\end{array}$} \\
\hline & \multicolumn{2}{|c|}{ Baik } & \multicolumn{2}{|c|}{ Buruk } & & & \\
\hline & $\mathbf{N}$ & $\%$ & $\mathbf{N}$ & $\%$ & & & \\
\hline Baik & 18 & 25,4 & 53 & 74,6 & 71 & 100 & 0,0399 \\
\hline Kurang & 19 & 46,3 & 22 & 53,7 & 41 & 100 & \\
\hline Jumlah & 37 & & 75 & 112 & & & \\
\hline
\end{tabular}

Dari data tabel 6 diatas dapat dilihat bahwa perilaku seksual remaja dengan pengetahuan yang baik berjumlah 71 responden di mana pengetahuan remaja baik dengan perilaku seksual remaja baik sebanyak 18 responden $(25,4 \%)$ lebih sedikit dibandingkan dengan pengetahuan remaja baik dengan perilaku seksual remaja yang Buruk sebanyak 53 responden $(74,6 \%)$, sedangkan perilaku seksual remaja dengan pengetahuan kurang berjumlah 41 responden yang pengetahuan kurang dengan perilaku seksual remaja yang baik sebanyak 19 responden $(46,3 \%)$ lebih kecil di bandingkan dengan pengetahuan remaja kurang dengan perilaku seksual remaja yang buruk sebanyak 22 responden $(53,7 \%)$. 
Bila di lihat dari hasil statistik dengan menggunakan Chi-Square menunjukan nilai p.value $(0,039)$ lebih kecil dari $\alpha(0,54)$ artinya ada hubungan bermakna antara pengetahuan dengan perilaku seksual remaja.

\section{Hubungan Antara Pengaruh Teman Sebaya dengan Perilaku Seksual Remaja}

Penelitian ini dilakukan pada 112 responden dimana pengaruh Teman Sebaya dikelompokan menjadi 2 kategori yaitu pengaruh teman sebaya baik dan pengaruh teman sebaya kurang baik dengan perilaku seksual baik dan perilaku seksual buruk dengan menggunakan uji statistik Chi-Square. Untuk mengetahui lebih jelas dapat di lihat pada tabel 7 di bawah ini :

Tabel 7 Distribusi Hubungan Pengaruh Teman Sebaya dengan Perilaku Seksual Remaja di SMK Karya Ibu Palembang

\begin{tabular}{|c|c|c|c|c|c|c|c|}
\hline \multirow{3}{*}{$\begin{array}{c}\text { Pengaruh } \\
\text { Teman } \\
\text { Sebaya }\end{array}$} & \multicolumn{4}{|c|}{$\begin{array}{c}\text { Perilaku seksual } \\
\text { remaja }\end{array}$} & \multirow[t]{3}{*}{ Total } & \multirow[t]{3}{*}{$\%$} & \multirow{3}{*}{$\begin{array}{c}P \\
\text { value }\end{array}$} \\
\hline & \multicolumn{2}{|c|}{ Baik } & \multicolumn{2}{|c|}{ Buruk } & & & \\
\hline & $\mathbf{N}$ & $\%$ & $\mathbf{N}$ & $\%$ & & & \\
\hline Baik & 24 & 27,3 & 64 & 72,7 & 88 & 100 & 0,025 \\
\hline Kurang & 13 & 54,2 & 11 & 45,8 & 24 & 100 & \\
\hline Jumlah & 37 & & 75 & & 112 & & \\
\hline
\end{tabular}

Dari data tabel 7 diatas dapat dilihat bahwa perilaku seksual remaja dengan pengaruh teman sebaya yang baik berjumlah 88 responden di mana pengaruh teman sebaya dengan perilaku seksual remaja baik sebanyak 24 responden $(27,3 \%)$ lebih sedikit dibandingkan dengan pengaruh teman sebaya baik dengan perilaku seksual remaja yang buruk sebanyak 64 responden $(72,7 \%)$, sedangkan perilaku seksual remaja dengan pengaruh teman sebaya kurang berjumlah 24 responden yang pengaruh teman sebaya kurang dengan perilaku seksual remaja yang baik sebanyak 13 responden $(54,2 \%)$ lebih besar di banding dengan pengaruh teman sebaya kurang dengan perilaku seksual remaja yang buruk sebanyak 11 responden $(45,8 \%)$.

Bila di lihat dari hasil statistik dengan menggunakan Chi-Square menunjukan nilai p.value $(0,025)$ lebih kecil dari $\alpha(0,05)$ artinya ada hubungan bermakna antara pengaruh teman sebaya dengan perilaku seksual remaja.

\section{PEMBAHASAN}

\section{Perilaku Seksual Remaja}

Perilaku seksual adalah segala tingkah laku yang didorong oleh hasrat seksual, baik dengan lawan jenis, maupun dengan sesama jenis. Bentuk-bentuk tingkah laku ini bisa bermacam-macam. Mulai dari perasaan tertarik sampai tingkah laku berkencan, bercumbu, dan bersenggama. Objek seksualnya bisa berupa orang lain, orang dalam khayalan atau diri sendiri. ${ }^{8}$

Pada penelitian ini menunjukan bahwa dari 112 responden berperilaku seksual Buruk sebanyak 75 responden (67\%) lebih besar di banding dengan responden yang berperilaku seksual baik sebanyak 37 responden (33\%).

Dampak dari perilaku seksual (yang dilakukan sebelum waktunya) antara lain dampak psikologis yang sangat serius seperti rasa bersalah, depresi, marah dan agresi. Semantara akibat psikososial yang timbul akibat perilaku seksual antara lain adalah ketegangan mental dan kebingungan akan peran sosial yang tiba-tiba berubah, misalnya pada kasus remaja hamil di luar nikah, di samping itu tingkat putus sekolah remaja hamil yang sangat tinggi, hal ini disebabkan 4 rasa malu remaja dan penolakan sekolah menerima kenyataan adanya murid hamil di luar nikah, masalah ekonomi juga akan membuat permasalahan ini menjadi rumit dan kompleks. ${ }^{9}$

\section{Pengaruh Orang Tua}

Dari hasil analisa univariat didapatkan bahwa responden dengan pengaruh orang tua yang baik sebanyak 89 reponden $(79,5 \%)$ lebih besar di banding dengan pengaruh orang tua yang kurang sebanyak 23 responden $(20,5 \%)$.

Dari hasil analisa bivariat perilaku seksual remaja dengan pengaruh orang tua yang baik berjumlah 89 responden di mana proporsi pengaruh orang tua dengan perilaku seksual remaja baik sebanyak 22 responden $(24,7 \%)$ lebih sedikit dibandingkan dengan proporsi pengaruh orang tua baik dengan perilaku seksual remaja yang buruk sebanyak 67 responden $(75,3 \%)$, sedangkan proporsi perilaku seksual remaja dengan pengaruh orang tua kurang berjumlah 23 responden yang pengaruh orang tua kurang dengan perilaku seksual remaja yang baik sebanyak 15 responden $(65,2 \%)$ lebih besar di bandingkan dengan proporsi pengaruh orang 
tua kurang dengan perilaku seksual remaja yang buruk sebanyak 8 responden $(34,8 \%)$. Bila di lihat dari hasil statistik dengan menggunakan Chi-Square menunjukan nilai $p$ value $=0,001<\alpha(0,05)$ artinya ada hubungan bermakna antara pengaruh orang tua dengan perilaku seksual remaja.

Berdasarkan penelitian Rizki pada tahun 2011 dengan jumlah responden sebanyak 95 responden, didapatkan hasil bahwa responden yang pengaruh orang tuanya baik sebanyak 30 responden $(46,2 \%)$, sedangkan yang pengaruh orang tuanya kurang sebanyak 35 responden $(53,8 \%)$. Dari hasil bivariat jumlah responden yang berprilaku seksual kurang baik dengan pengaruh orang tua kurang sebesar $21(60 \%)$ lebih besar dari pada responden yang pengaruh orang tuanya baik sebanyak 9 (30\%). Pada uji statistic Chi-square menunjukan ada hubungan yang bermakna antara pengaruh orang tua dengan perilaku seksual dengan $p$ value $=0,030{ }^{10}$

Pola asuh sangat mempengaruhi peran dan fungsi keluarga. Pengaruh keluarga dalam pembentukan dan perkembangan kepribadian anak sangat besar diantaranya sikap orang tua yang otoriter (mau menang sendiri, selalu mengatur), sikap orang tua yang permisif (serba tidak boleh, pernah melarang, selalu menuruti kehendak anak, selalu memanjakan. ${ }^{11}$

\section{Pengetahuan}

Dari hasil analisis univariat didapatkan responden dengan pengetahuan baik sebanyak 71 reponden $(63,4 \%)$ lebih besar di banding dengan responden yang berpengetahuan kurang sebanyak 41 responden $(36,6 \%)$.

Dari hasil analisa bivariat didapatkan bahwa perilaku seksual remaja dengan pengetahuan yang baik berjumlah 71 responden di mana proporsi pengetahuan remaja baik dengan perilaku seksual remaja baik sebanyak 18 responden $(25,4 \%)$ lebih sedikit dibandingkan dengan proporsi pengetahuan remaja baik dengan perilaku seksual remaja yang buruk sebanyak 53 responden $(74,6 \%)$, sedangkan proporsi perilaku seksual remaja dengan pengetahuan kurang berjumlah 41 responden yang pengetahuan kurang dengan proporsi perilaku seksual remaja yang baik sebanyak 19 responden $(46,3 \%)$ lebih kecil di bandingkan dengan proporsi pengetahuan remaja kurang dengan perilaku seksual remaja yang buruk sebanyak 22 responden $(53,7 \%)$. Berdasarkan penelitian Tirta di SMA Negeri 13 Palembang tahun 2008 dengan jumlah responden sebanyak 192 orang didapatkan hasil analisis univariat menunjukkan responden yang berpengetahuan kurang yaitu sebanyak 109 responden $(56,8 \%)$ dan yang berpengetahuan baik yaitu 83 responden (43,2\%). Hasil analisis bivariat junlah responden yang berpengetahuan baik dengan perilaku seks baik lebih besar yaitu 48 responden $(57,8 \%)$ dan responden yang berpengetahuan kurang dengan perilaku seks baik yaitu sebesar 22 responden (20,2\%). Hasil uji Chi-Square didapatkan nilai $\mathrm{P}$ Value $(0,000)$ berarti ada hubungan yang bermakna antara pengetahuan seks dengan perilaku seks.

Masyarakat masih sangat mempercayai pada mitos-mitos seksual yang merupakan salah satu pemahaman yang salah tentang seksual. Kurangnya pemahaman ini disebabkan oleh berbagai faktor antara lain : adat istiadat, budaya, agama dan kurangnya informasi dari sumber yang benar. ${ }^{12}$

Bila di lihat dari hasil statistik dengan menggunakan Chi-Square menunjukan nilai p.value $(0,039)$ lebih kecil dari $\alpha(0,05)$ artinya ada hubungan bermakna antara pengetahuan dengan perilaku seksual remaja.

\section{Pengaruh Teman Sebaya}

Dari hasil analisa univariat didapatkan bahwa responden yang mempunyai teman sebaya baik sebanyak 88 reponden $(78,6 \%)$ lebih besar di banding dengan responden yang mempunyai teman sebaya kurang baik sebanyak 24 responden $(21,4 \%)$.

Dari hasil analisa bivariat didapat bahwa perilaku seksual remaja dengan pengaruh teman sebaya yang baik berjumlah 88 responden di mana proporsi pengaruh teman sebaya baik dengan perilaku seksual remaja baik sebanyak 24 responden $(27,3 \%)$ lebih sedikit dibandingkan dengan proporsi pengaruh teman sebaya baik dengan perilaku seksual remaja yang buruk sebanyak 64 responden $(72,7 \%)$, sedangkan perilaku seksual remaja dengan pengaruh teman sebaya kurang berjumlah 24 responden yang proporsi pengaruh teman sebaya kurang dengan perilaku seksual remaja yang baik sebanyak 13 responden $(54,2 \%)$ lebih sedikit di bandingkan dengan proporsi pengaruh orang 
tua kurang dengan perilaku seks ual remaja yang buruk sebanyak 11 responden $(45,8 \%)$.

Bila di lihat dari hasil statistik dengan menggunakan Chi-Square menunjukan nilai p.value $(0,025)$ lebih kecil dari $\alpha(0,05)$ artinya ada hubungan bermakna antara pengaruh orang tua dengan perilaku seksual remaja.

Berdasarkan penelitian Rizki pada tahun 2011 dengan jumlah responden sebanyak 65 responden, dari hasil univariat didapatkan bahwa responden yang mempunyai teman sebaya yang baik sebanyak 30 responden $(46,2 \%)$, sedangkan responden yang mempunyai teman sebaya kurang baik yaitu sebanyak 35 responden $(53,8 \%)$. Dari hasil bivariat, jumlah responden yang berprilaku seksual baik dengan teman sebaya baik sebesar 21 (30\%) sama dengan responden yang mempunyai teman sebaya kurang baik sebesar 21 (70\%). Pada uji statistic Chi-square menunjukan ada hubungan yang bermakna antara teman sebaya dengan perilaku seksual dengan $\mathrm{p}$ value $=$ 0,030 lebih kecil dari $\alpha=0,05 .{ }^{10}$

Kelompok sebaya memberikan lingkungan, yaitu dunia tempat remaja dapat melakukan sosialisasi dimana nilai yang berlaku bukanlah nilai yang ditetapkan oleh orang dewasa melainkan oleh teman yang seusianya. Inilah letak bahayanya bagi perkembangan jiwa remaja, apabila nilai yan $\mathrm{g}$ dikembangkan dalam kelompok sebayaadalah nilai yang negative. Akan lebih berbahaya lagi apabila sekelompok sebaya ini tertutup, dimana setiap anggota tidak terlepas dari kelompoknya dan harus mengikuti nilai yang dikembangkan oleh pimpinan kelompok. Sikap, pikiran, perilaku, dan gaya hidupnya merupakan perilaku dan gaya hidup kelompoknya. ${ }^{11}$

\section{KESIMPULAN}

Ada hubungan bermakna antara pengaruh orang tua dengan perilaku seksual remaja dengan p.value yaitu 0,001. Ada hubungan bermakna antara pengetahuan dengan perilaku seksual remaja dengan $p$ value yaitu 0,039 . Ada hubungan bermakna antara pengaruh teman sebaya dengan perilaku seksual remaja dengan $p$ value yaitu 0,025 .

\section{DAFTAR PUSTAKA}

1. Kusmiran, Eny. 2011. Kesehatan Reproduksi Remaja dan Wanita. Jakarta : Salemba Medika.

2. Muzzayanah, Nurul. 2010. Perilaku Seksual Remaja dan Kesehatan Reproduksi. (http://yantiglobel.wordpreMass.com,

3. Yudana, 2009.http://digilib.unimus.ac.id/files/disk1/11 9/jtptunimus-gdl-sitifatima-5906-1-11.bab.pdf.

4. Admin, 2008. Perilaku Seksual. (http://www.kesrepro.info/?q=node/383.

5. Handani, Rizki. 2011. http://bs-ba facebook.com.

6. Purnawan, Iwan. 2005. Faktor-faktor yang mempengaruhi perilaku seksual pada Anak Jalanan. Yogyakarta : Program Studi Ilmu Keperawatan, Fakultas Kedokteran.

7. Notoadmodjo, soekidjo. 2010. Metodelogi Penelitian. Jakarta : Rineka Cipta.

8. Faisal, 2010. 10 Penyebab Kenakalan Remaja. (http://www.garutkab.go.id/download

files/article/10 penyebab kenakalan
remaja.pdf.

9. Mu'tadin, Zainun. 2008. http://ilmuPsikologi.com.

10.Rizki, Indah dwi. 2011. Faktor-faktor yang berhubungan dengan perilaku seks remaja di Madrasah Aliyah (MA) Palembang. Tesis

11.Depkes RI. 2008. Yang Perlu diketahui Petugas Kesehatan Tentang : Kesehatan Reproduksi. Jakarta : Depkes RI.

12. Soetjiningsih, 2007. http://digilib.unimus.ac.id/files/disk1/119/jtptu nimus-gdl-sitifatima-5906-1-11.bab-.pdf. 
